\title{
INFLUENCE OF DIFFERENT TREATMENTS ON THE CORROSION BEHAVIOUR OF AN Fe-BASED BIODEGRADABLE ALLOY
}

\author{
VPLIV RAZLIČNIH OBDELAV NA KOROZIJSKO OBNAŠANJE \\ BIORAZGRADLJIVE ZLITINE NA OSNOVI Fe
}

\author{
Irena Paulin \\ Institute of Metals and Technology, Lepi pot 11, SI-1000 Ljubljana, \\ Prejem rokopisa - received: 2020-12-01; sprejem za objavo - accepted for publication: 2020-12-15
}

doi:10.17222/mit.2020.252

\begin{abstract}
Biodegradable alloys are required for medical applications involving temporary implants that must last for a certain time. Fe-based alloys were produced to last longer than $\mathrm{Mg}$ - or $\mathrm{Zn}$-based alternatives, while retaining a biodegradable characteristic so that no additional operation is necessary to remove the implant. The investigation of commonly used Fe-based alloys was directed towards a better corrosion resistance, while our aim was to produce a material that will corrode easily, but would initially still have mechanical properties like Fe-based materials. This aim was achieved by using different production steps, and the corrosion properties were found to be dependent on modifications to the microstructure.

Keywords: Fe-based biodegradable material, microstructure characterization, corrosion initials, mechanical properties

Biorazgradljive zlitine so potrebne za medicinske namene, ki vključujejo začasne vsadke, ki morajo trajati določeno časovno obdobje. Zlitine na osnovi Fe so bile narejene tako, da trajajo dlje kot alternative na osnovi Mg ali Zn, hkrati pa ohranjajo biološko razgradljive lastnosti, tako da za odstranitev vsadka ni potrebna dodatna operacija. Preiskava pogosto uporabljenih zlitin na osnovi Fe je bila usmerjena v boljšo odpornost proti koroziji, naš cilj pa je bil izdelati material, ki bo zlahka korodiral, vendar bi imel na začetku še vedno mehanske lastnosti kot materiali na osnovi Fe. Ta cilj je bil dosežen z uporabo različnih proizvodnih korakov in ugotovljeno je bilo, da so korozijske lastnosti odvisne od sprememb mikrostrukture.

Ključne besede: biorazgradljive zlitine na osnovi Fe, karakterizacija mikrostrukture, korozijski iniciali, mehanske lastnosti
\end{abstract}

\section{INTRODUCTION}

The most used biodegradable materials for biomedical applications are $\mathrm{Mg}$ - and $\mathrm{Zn}$-based alloys. However, these alloys tend to degrade too quickly and produce too much in terms of corrosion products in a relatively short time during their degradation in the body. This means that such materials are only useful for applications that involve a short period of time in living tissue.

Recently, research has been extended to Fe-based alloys. The benefits of these alloys are a longer lifetime in the body, which is a major advantage for specific treatments and healing requirements. When healing injuries and fractures, for example, implants made from stainless steel are used for bone stabilization. However, such materials need to be removed after a successful treatment. Biodegradable materials are expected to corrode gradually in the body, with an appropriate host response elicited by the released corrosion products that dissolve completely upon fulfilling their role to assist with tissue healing, and with no implant residues. The limitation of such a material is that the time to degrade in vivo could be too long. Though the material needs to be biocompatible, without harmful reactions with the body, no

*Corresponding author's e-mail:

irena.paulin@imt.si (Irena Paulin) additional compounds are necessary to alter the corrosion properties. Nevertheless, a too rapid degradation also means too much corrosion product in the body over a short period of time. As a result, all the parameters need to be optimized to prevent harm to the body.

In the Fe-Mn system for Mn contents below 30 w/\% a phase transformation from the austenitic to the ferritic structure occurs upon cooling (see the Fe-Mn equilibrium phase diagram). This transformation requires significant changes in the phase compositions. Upon rapid cooling from elevated temperatures (above $900{ }^{\circ} \mathrm{C}$ ), diffusion is limited and martensitic phase transformations occur. ${ }^{1} \mathrm{Mn}$ lowers the standard electrode potential $\left(E^{0}\right)$ of iron: the standard potential of the reaction $\mathrm{Fe} \rightarrow \mathrm{Fe}^{2+}+2 \mathrm{e}^{-}$ is $E_{1}=-0.440 \mathrm{~V}$, whereas that of $\mathrm{Mn} \rightarrow \mathrm{Mn}^{2+}+2 \mathrm{e}^{-}$is $E_{2}=$ $-1.18 \mathrm{~V}^{2}{ }^{2}$ Because $\mathrm{Fe}$ and $\mathrm{Mn}$ form a solid solution the standard potential of the Fe-Mn alloy is expected to decrease with an increasing Mn content. ${ }^{3} \mathrm{H}$. Hermawan et al. ${ }^{4-6}$ claim that the corrosion rates for alloys with different $\mathrm{Mn}$ contents from $20 \mathrm{w} / \%$ to $35 \mathrm{w} / \%$, exhibited no significant difference. All the rates were in the range $0.23-0.24 \mathrm{~mm} /$ year. $^{4}$

In the present study we focused on the synthesis of $\mathrm{Fe}-\mathrm{Mn}$ alloys, ${ }^{7-11}$ which are known as biodegradable materials, but have limitations with using different chemical elements that can be harmful to a living body. ${ }^{12-14}$ We in- 
vestigated the possibilities of producing an $\mathrm{Fe}-\mathrm{Mn}$ alloy with either minimal or no additional elements and still increase the corrosion susceptibility with commonly used production steps. The aim was to produce a material without additional elements to decrease the electrode potential with controllable microstructural and mechanical properties, and with a faster degradation. The study was focused on microstructural characterizations, mechanical testing and corrosion testing in artificial physiological solutions.

\section{EXPERIMENTAL PART}

The Fe-Mn alloy with 17 w/\% Mn was produced using conventional production steps, such as casting in a steel mould and hot rolling to achieve better mechanical properties by altering the microstructure. Additionally, part of the hot-rolled material was cold deformed by forging ( $15 \%$ reduction). After each production step, all three materials were studied to reveal the impact on the microstructural, electrochemical and mechanical properties and compared to pure Fe.

The chemical composition of the alloy and the pure Fe was measured using an X-ray fluorescence (XRF) spectrometer. The results are shown in Table 1. The material was characterised using a scanning electron microscope coupled with an energy-dispersive spectrometer (SEM, JEOL JSM-6500F, EDS INCA X-SIGHT LH2-type detector, INCA ENERGY 450) to analyse the chemical compositions of the phases. The microstructure

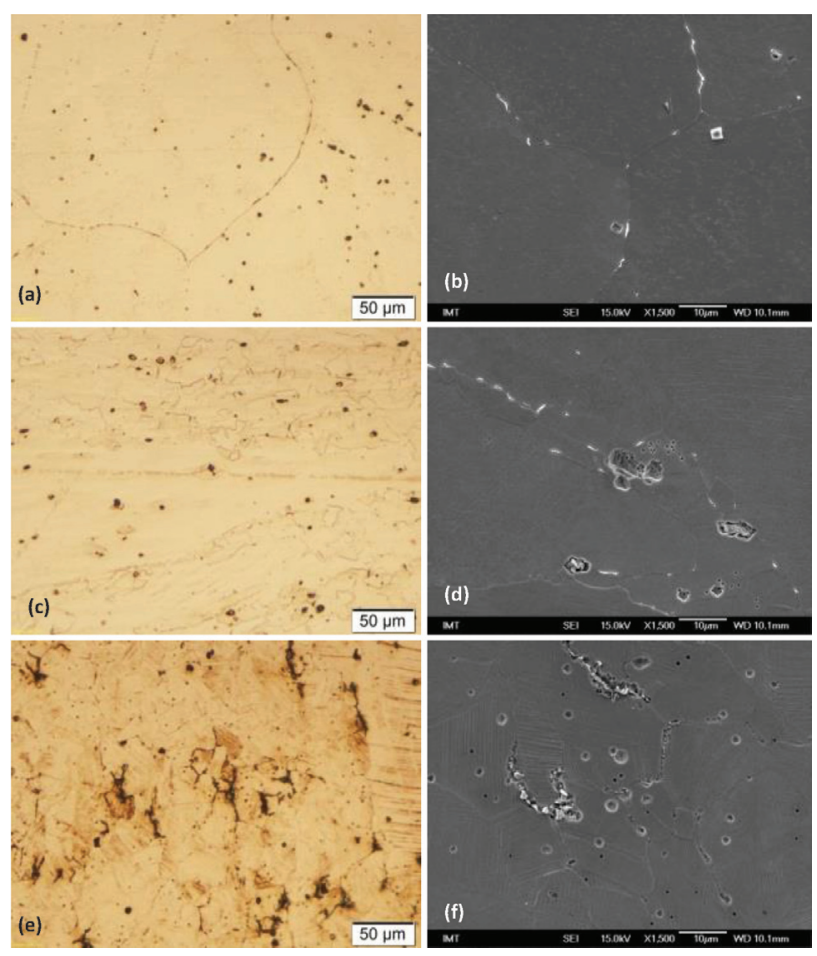

Figure 1: Micrographs of the microstructure: a) cast, LM, b) as-cast, SEM, c) hot rolled, LM, d) hot rolled, SEM, e) cold deformed, LM and f) cold deformed, SEM was also analysed using light microscopy (LM, Microphot FXA Nikon with Olympus DP73) and the mechanical testing was performed with an INSTRON 1255 and the Vickers hardness with an Instron Tukon $2100 B$.

\section{RESULTS AND DISCUSSION}

The chemical compositions of the investigated materials are presented in Table $\mathbf{1}$. While the main difference between the alloys is in the Mn content there are also small differences in the $\mathrm{Si}, \mathrm{Cr}$ and $\mathrm{Cu}$ contents.

Table 1: XRF results of chemical compositions (Fe Balance) / w/ \%

\begin{tabular}{|l|c|c|c|c|c|}
\hline & $\mathrm{Si}$ & $\mathrm{Mn}$ & $\mathrm{Cr}$ & $\mathrm{Cu}$ & $\mathrm{Ni}$ \\
\hline FeMn17 & 0.17 & 17.07 & 0.70 & 0.44 & 0.18 \\
\hline Pure Fe & 0.051 & 0.26 & 0.14 & 0.043 & 0.14 \\
\hline
\end{tabular}

The microstructures of the cast, hot-rolled and cold-deformed FeMn17 alloys are shown in Figure 1. There is no difference in the chemical composition, but there are differences in the microstructure. In the cast sample (Figures 1a to 1b) the cast austenitic microstructure occurs upon cooling. Due to the very fast cooling rate, there is no time for the phase transformation. There are also some boundary segregations rich in $\mathrm{Cu}$ (Figure 2, EDS Spectrum 2). In the hot-rolled sample we observed, besides the austenite, traces of strain-induced martensite and deformation twins. Due partly to recrystallization, the microstructure consists of large and small grains. In the cold-deformed sample (Figures 1e to 1f) the microstructure has even smaller grains, the segregation is still ubiquitous at the grain boundaries and the austenite with a strain-induced martensitic structure is present. Some porosity was also found in the cast samples. The EDS analyses (Figure 2, Table 2) were performed to determine the phases and inclusions in the

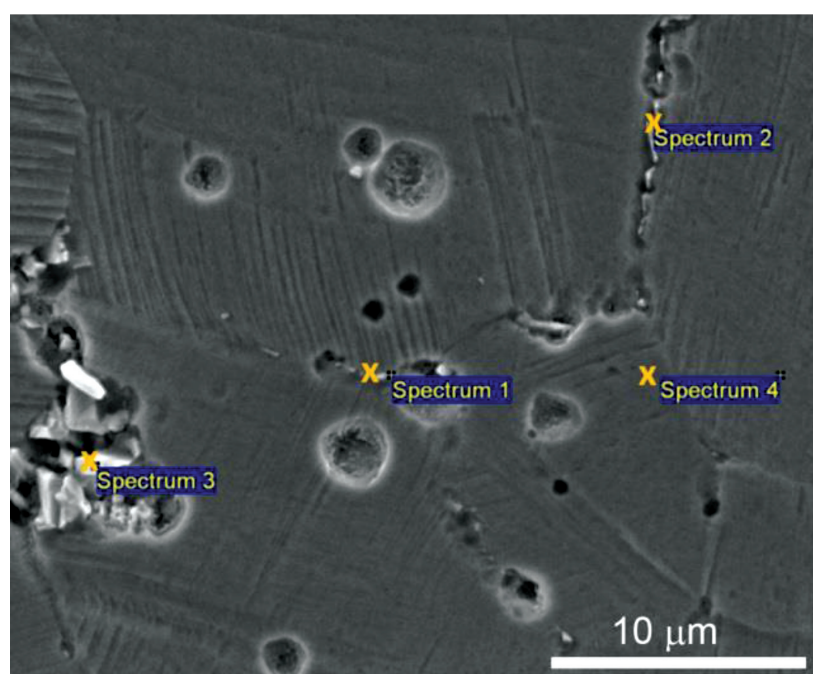

Figure 2: SEM image and EDS analysis of cold-deformed sample 
microstructure. Some TiN and MnS inclusions are present in all the samples.

Table 2: EDS results (marked in Figure 2) of chemical compositions in $w / \%$

\begin{tabular}{|c|c|c|c|c|c|c|}
\hline Spectrum & $\mathrm{O}$ & $\mathrm{Si}$ & $\mathrm{Cr}$ & $\mathrm{Mn}$ & $\mathrm{Fe}$ & $\mathrm{Cu}$ \\
\hline Spectrum 1 & 3.2 & 0.4 & 1.0 & 20.3 & 75.1 & - \\
\hline Spectrum 2 & 4.8 & 0.4 & 0.7 & 18.6 & 73.1 & 2.4 \\
\hline Spectrum 3 & 3.5 & - & 1.6 & 30.3 & 64.6 & - \\
\hline Spectrum 4 & - & - & 0.8 & 19.2 & 80.0 & - \\
\hline
\end{tabular}

Mechanical testing was performed on standard prepared samples and the averages of the results are displayed in Table 3. The results of our materials, the pure $\mathrm{Fe}$ and the human compact bones, ${ }^{15,16}$ were compared.

Table 3: Hardness and mechanical testing

\begin{tabular}{|c|c|c|c|c|c|}
\hline Sample & $\begin{array}{c}\text { As } \\
\text { cast }\end{array}$ & $\begin{array}{c}\text { Hot } \\
\text { rolled }\end{array}$ & $\begin{array}{c}\text { Cold } \\
\text { de- } \\
\text { formed }\end{array}$ & Pure Fe & $\begin{array}{c}\text { Com- } \\
\text { pact } \\
\text { bone }^{15}\end{array}$ \\
\hline HV 5 & 181 & 240 & 478 & 110 & $50-100$ \\
\hline$R_{\mathrm{p} 0,2} / \mathrm{MPa}$ & 300 & 350 & 340 & 170 & - \\
\hline$R_{\mathrm{m}} / \mathrm{MPa}$ & 705 & 955 & 908 & 270 & $90-130$ \\
\hline Elongation A / \% & 45 & 62 & 62 & 49 & $0.5-3^{16}$ \\
\hline
\end{tabular}

All the samples were immersed in Hank's solution, which has an ionic composition and concentration close to that of human blood plasma. The corrosion rates were measured (results in Table 4) and compared with the results from. ${ }^{4}$

Table 4: Corrosion rates in Hank's solution in mm/year

\begin{tabular}{|c|c|c|c|}
\hline Samples & \multicolumn{3}{|c|}{ FeMn17 } \\
\hline & Cast & Hot rolled & Cold deformed \\
\hline CR & 0.17 & 0.09 & 0.21 \\
\hline \multicolumn{4}{|c|}{ Samples } \\
\hline Pure Fe & FeMn20* & FeMn30* & FeMn35* \\
\hline 0.05 & \multicolumn{3}{|c|}{$0.22-0.24$} \\
\hline
\end{tabular}

*Results from the references: ${ }^{4,6,17}$

\section{CONCLUSIONS}

An FeMn17 alloy was produced with a variety of commonly used production steps to develop different microstructures without any additional elements. The microstructures, mechanical properties and corrosion resistances were investigated and the results compared to pure Fe. The investigations performed so far all studied the influence of different $\mathrm{Mn}$ contents and the addition of elements that form intermetallic inclusions to increase the corrosion rate. Our study was performed to investigate the influence of different microstructures on the corrosion rates for the same chemical composition. The corrosion results were combined with the mechanical properties and some useful conclusions were drawn:

- The corrosion rates for biodegradable Fe-Mn alloys with different chemical compositions and treatments were not so different, they were all in the range $0.1-0.25 \mathrm{~mm} /$ year. $^{4}$

- The different Mn contents influence the microstructure and therefore indirectly influence the corrosion and mechanical properties. From our results it is evident that the microstructure has an important influence, which means that the corrosion rate can be altered simply by employing different production steps.

- As intermetallic inclusions with Pd and other elements that lower the electrode potential help to decrease the corrosion resistance, the porosity, grain size, phases and boundary segregation also have a great influence on the corrosion rate. Therefore, the corrosion rate is higher when we have cast material with porosity and segregations, and also the corrosion rate increases when we have cold-deformed material that has a martensitic structure with internal strain and also some segregation at the grain boundary (Cu-rich segregations in our case). All these initials in the material provide micro-galvanic sites and increase the tendency to corrode more than, or the same as, increasing the Mn content.

- The implant material for different healing processes needs to have similar mechanical properties to bone, so that it is useful for the healing process and it is not a problem for the body if another injury at the affected part occurs. Therefore, it is essential for the material to have good mechanical properties at the beginning, which then decrease over time because of the degradation in the body. It is also important that the fractures of the material are rounded, rather than sharp.

\section{Acknowledgments}

The authors acknowledge the financial support from the Slovenian Research Agency, research core funding No. J2-1729 and P2-0132.

Responsible person for English translation is Asst/Prof Dr Paul McGuiness, Ljubljana, Slovenia

\section{REFERENCES}

${ }^{1}$ M. Schinhammer, A. C. Hänzi, J. F. Löffler, P. J. Uggowitzer, Design strategy for biodegradable Fe-based alloys for medical applications, Acta Biomaterialia 6 (2010) 1705-1713, doi:10.1016/j.actbio.2009. 07.039

${ }^{2}$ Revie WR, Uhlig HH. Corrosion and corrosion control. New York: John Wiley, 2008

${ }^{3}$ A. Kawashima, K. Asami, K. Hashimoto, Effect of manganese on the corrosion behaviour of chromium-bearing amorphous metal-metalloid alloys, Sci Rep Res Inst Tohoku Univ Phys Chem Metall 29 (1981) 2, 276-83

${ }^{4}$ H. Hermawan, D. Dubé, D. Mantovani, Degradable metallic biomaterials: Design and development of Fe-Mn alloys for stents, Journal of Biomedical Materials Research Part A, 93 (2010) 1, 1-11, doi:10.1002/jbm.a.32224 


\section{PAULIN: INFLUENCE OF DIFFERENT TREATMENTS ON THE CORROSION BEHAVIOUR ...}

${ }^{5}$ H. Hermawan, Biodegradable Metals: From Concept to Applications, 1st ed., Springer, Berlin 2012, 69, doi:10.1007/978-3-642-31170-3

${ }^{6}$ Y. F. Zheng, X. N. Gu, F. Witte, Biodegradable metals, Materials Science and Engineering: R: Reports, 77 (2014) 1-34, doi:10.1016/ j.mser.2014.01.001

${ }^{7}$ B. Liu, Y. F. Zheng, L. Ruan, In vitro investigation of Fe30Mn6Si shape memory alloy as potential biodegradable metallic material, Materials Letters, 65 (2011) 3, 540-543, doi:10.1016/j.matlet. 2010.10.068

${ }^{8}$ D. Vojtěch, J. Kubásek, J. Čapek, I. Pospíšilová, Comparative mechanical and corrosion studies on magnesium, zinc and iron alloys as biodegradable metals, Materials and technology, 49 (2015) 6 , 877-882, doi:10.17222/mit.2014.129

${ }^{9}$ J. Čapeka, J. Kubásek, D. Vojtěch, E. Jablonská, J. Lipov, T. Ruml, Microstructural, mechanical, corrosion and cytotoxicity characterization of the hot forged FeMn30(wt.\%) alloy, Materials Science and Engineering: C1m 58 (2016), 900-908, doi:10.1016/j.msec.2015. 09.049

${ }^{10}$ M. C. Conti, Daniel, A. J. Buhagiar, Influence of cold rolling on in vitro cytotoxicity and electrochemical behaviour of an Fe-Mn-C biodegradable alloy in physiological solutions, Heliyon vol. 4 (2018) 11, doi:10.1016/j.heliyon.2018.e00926

${ }^{11}$ P. S. Baghaa, M. Khakbiza, S. Sheibanib, H. Hermawan, Design and characterization of nano and bimodal structured biodegradable $\mathrm{Fe}-\mathrm{Mn}-\mathrm{Ag}$ alloy with accelerated corrosion rate, Journal of Alloys and Compounds, 767 (2018) 955-965, doi:10.1016/j.jallcom.2018. 07.206

${ }^{12}$ J. Kubásek, I. Pospísilová, D. Vojtìch, E. Jablonská, T. Ruml, Structural, mechanical and cytotoxicity characterization of as-cast biodegradable $\mathrm{Zn}-\mathrm{xMg}(\mathrm{x}=0.8-8.3 \%)$ alloys, Mater. Tehnol., 48 (2014) $5,623-629$

${ }^{13}$ D. Pihura, M. Oruč, J. Lamut, Selective oxidation of manganese in molten pig iron, Mater. Tehnol., 44 (2010) 5, 235-238

${ }^{14}$ Č. Donik, A. Kocijan, I. Paulin, M. Hočevar, P. Gregorčič, M. Godec, Improved Biodegradability of Fe-Mn Alloy After Modification of Surface Chemistry and Topography by a Laser Ablation, Applied Surface Science (2018), 453, doi:10.1016/j.apsusc.2018.05.066

${ }^{15}$ A. D. P. Bankoff, Biomechanical Characteristics of the Bone, Human Musculoskeleta Biomechanics, T. Goswami (ed.), InTech, (2012) 61-86, doi: $10.5772 / 19690$

${ }^{16}$ Mechanical properties of bone, DoITPoMS, University of Cambridge (August 2011), http://www.doitpoms.ac.uk/tlplib/bones/ bone_mechanical.php

${ }^{17}$ C. S. Obayi, R. Tolouei, A. Mostavan, C. Paternoster, S. Turgeon, B. A. Okorie, D. O. Obikwelu, D. Mantovani, Effect of grain sizes on mechanical properties and biodegradation behavior of pure iron for cardiovascular stent application; Biomatter. 6 (2016) 1; e959874 (9 pages), doi:10.4161/21592527.2014.959874. 